\title{
Erythrobacter flavus sp. nov., a slight halophile from the East Sea in Korea
}

\author{
Correspondence \\ Yong-Ha Park \\ yhpark@mail.kribb.re.kr
}

\author{
Jung-Hoon Yoon, ${ }^{1}$ Hongik Kim, ${ }^{2}$ In-Gi Kim, ${ }^{2}$ Kook Hee $\mathrm{Kang}^{3}$ and \\ Yong-Ha Park ${ }^{1,2}$
${ }^{1}$ Korea Research Institute of Bioscience and Biotechnology (KRIBB), PO Box 115, Yusong, Taejon, Korea \\ ${ }^{2}$ National Research Laboratory of Molecular Ecosystematics, Institute of Probionic, Probionic \\ Corporation, Bio-venture Center, Korea Research Institute of Bioscience and Biotechnology \\ (KRIBB), PO Box 115, Yusong, Taejon, Korea \\ ${ }^{3}$ Department of Food and Life Science, Sungkyunkwan University, Chunchun-dong 300, \\ Jangan-gu, Suwon, Korea
}

The genus Erythrobacter was proposed by Shiba \& Simidu (1982) to accommodate Gram-negative, ovoid to rodshaped and aerobic chemo-organotrophs. Species of this genus are red or orange in colour and contain bacteriochlorophyll $a$ and carotenoids (Shiba \& Simidu, 1982; Yurkov et al., 1994). However, a novel Erythrobacter species that produces a yellow pigment and lacks bacteriochlorophyll $a$, Erythrobacter citreus, has recently been described (Denner et al., 2002). Phylogenetic analyses based on 16S rDNA sequences have shown that the genus Erythrobacter falls within the $\alpha$-subclass of the Proteobacteria and is closely related to the genera Erythromicrobium and Porphyrobacter (Yurkov et al., 1994; Anzai et al., 2000; Denner et al., 2002).

Published online ahead of print on 21 March 2003 as DOI 10.1099/ ijs.0.02510-0.

Abbreviation: FAME, fatty acid methyl ester.

The GenBank/EMBL/DDBJ accession numbers for the 16S rDNA sequences of strains SW-46 ${ }^{\top}$ and SW-52 are AF500004 and AF500005, respectively.
The classification of Erythrobacter as a genus separate from Erythromicrobium and Porphyrobacter is warranted by only small phenotypic differences (Shiba, 1991; Fuerst et al., 1993; Yurkov et al., 1994). However, the separation of the cluster that comprises Erythrobacter from the cluster that comprises the genera Erythromicrobium and Porphyrobacter has been supported by a high bootstrap resampling value (Denner et al., 2002). Nevertheless, the three genera mentioned above may have to be taxonomically reevaluated by using additional phenotypic, particularly chemotaxonomic, data or detailed phylogenetic analysis.

There are three Erythrobacter species with validly published names: Erythrobacter longus (Shiba \& Simidu, 1982), Erythrobacter litoralis (Yurkov et al., 1994) and E. citreus (Denner et al., 2002). The genus Erythrobacter is characterized chemotaxonomically by having $\mathrm{C}_{18: 1}$ as the major fatty acid and by a DNA G + C content of 60-67 mol\% (Shiba \& Simidu, 1982; Fuerst et al., 1993; Yurkov et al., 1994). However, Shiba (1991) reported that the type strain of E. longus has a DNA G + C content of $57 \cdot 4 \mathrm{~mol} \%$. 
All three Erythrobacter species have been isolated from marine environments (Shiba \& Simidu, 1982; Yurkov et al., 1994; Denner et al., 2002). Recently, two slightly halophilic bacterial strains, $\mathrm{SW}-46^{\mathrm{T}}$ and $\mathrm{SW}-52$, were isolated from sea water of Hwajinpo Beach, East Sea, Korea. The two isolates were phylogenetically most closely related to the genus Erythrobacter, based on the result of $16 \mathrm{~S}$ rDNA sequence comparison. Colonies of the two strains were observed to be yellow on marine agar, unlike the first two Eythrobacter species that were described. Accordingly, the aim of the present study was to establish the exact taxonomic status of the two isolates by a polyphasic taxonomic approach. In this work, we describe the morphological, phenotypic, phylogenetic and genomic characteristics of strains SW $-46^{\mathrm{T}}$ and SW-52. On this basis, we propose a novel species of the genus Erythrobacter, Erythrobacter flavus sp. nov., for strains SW- $-46^{\mathrm{T}}$ and SW-52.

Strains SW $-46^{\mathrm{T}}$ and SW-52 ( = KCCM $41643=$ JCM 11809) were isolated by using the dilution-plating technique on marine agar 2216 (MA; Difco). E. longus DSM 6997 ${ }^{\mathrm{T}}$, E. litoralis DSM $8509^{\mathrm{T}}$ and E. citreus DSM $14432^{\mathrm{T}}$, which were obtained from DSMZ, Germany, were used as reference strains. Cell biomass of strains $\mathrm{SW}-46^{\mathrm{T}}$ and SW-52 and reference strains was obtained from marine broth 2216 (MB; Difco) cultures grown at $30^{\circ} \mathrm{C}$, for respiratory lipoquinone analysis and DNA extraction. All strains were cultivated on a gyratory shaker at 150 r.p.m. For fatty acid methyl ester (FAME) analysis, cell mass of strains SW- $46^{\mathrm{T}}$ and SW-52, E. longus DSM $6997^{\mathrm{T}}$ and E. litoralis DSM $8509^{\mathrm{T}}$ was obtained from agar plates after 5 days cultivation at $30^{\circ} \mathrm{C}$ on MA. Cell morphology was examined by light microscopy (Nikon E600) and transmission electron microscopy (TEM); presence or absence of flagella was examined by TEM using cells from exponentially growing cultures. The cells were negatively stained with $1 \%$ $(\mathrm{w} / \mathrm{v})$ phosphotungstic acid and, after air drying, the grids were examined by using a model CM-20 transmission electron microscope (Philips). Growth at various $\mathrm{NaCl}$ concentrations was investigated in $\mathrm{MB}$. Growth at $4-55^{\circ} \mathrm{C}$ was measured on MA. Growth under anaerobic conditions was determined after incubation in an anaerobic chamber with MA that had been prepared anaerobically. Presence or absence of bacteriochlorophyll $a$ was examined by registration of the in vitro absorption spectrum of a methanol extract of cells at 768-769 nm. Susceptibility to antibiotics was detected on agar plates by using antibiotic discs (concentrations shown in Table 1). Catalase activity was determined by bubble production in $3 \%(\mathrm{v} / \mathrm{v})$ hydrogen peroxide solution. Oxidase activity was determined by

Table 1. Differential phenotypic characteristics of Erythrobacter flavus sp. nov., E. longus, E. litoralis and E. citreus

+, Positive; -, negative; $\mathrm{W}+$, weakly positive; ND, not determined; $\mathrm{V}$, variable. Data in parentheses are for the type strain. All species are rod-shaped and positive for catalase and oxidase activities, susceptibility to chloramphenicol (100 $\mu$ g per disc; $30 \mu \mathrm{g}$ per disc for E. citreus) and utilization of acetate. All species are negative for Gram-staining, spore formation, motility, susceptibility to polymyxin B (100 U per disc; $300 \mathrm{U}$ per disc for E. citreus) and utilization of malate.

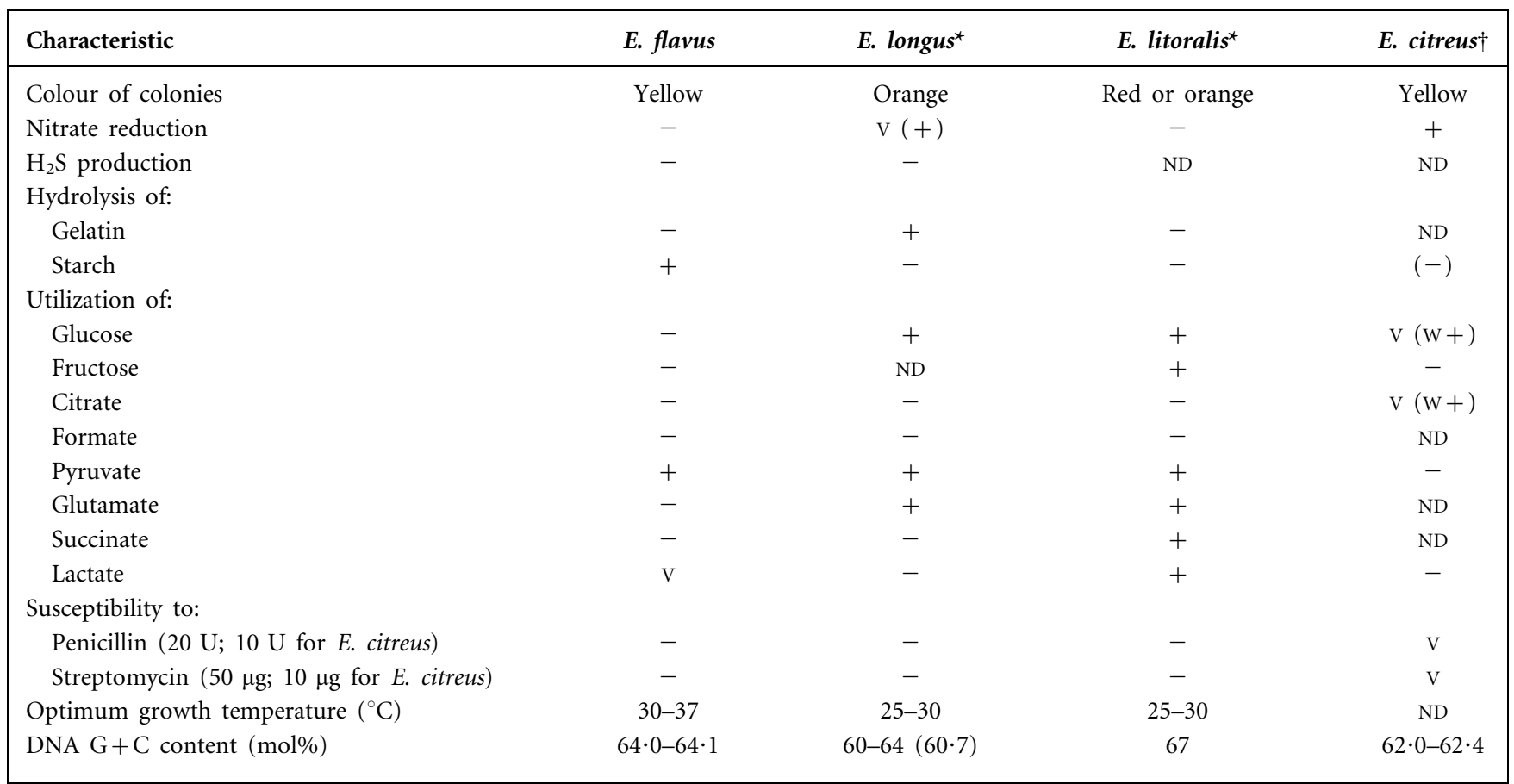

*Data from Shiba \& Simidu (1982) and Yurkov et al. (1994).

$\dagger$ Data from Vybiral et al. (1999) and Denner et al. (2002). 
oxidation of $1 \% p$-aminodimethylaniline oxalate. Hydrolysis of aesculin and nitrate reduction were determined as described by Lányi (1987). Hydrolysis of casein, starch and Tween 80 and urease activity were determined as described by Cowan \& Steel (1965). Hydrolysis of gelatin was studied as described by Cowan \& Steel (1965), with the modification that artificial sea water was used. The artificial sea water contained [(1 distilled water $)^{-1}$ ]: $23.6 \mathrm{~g} \mathrm{NaCl}$, $0.64 \mathrm{~g} \mathrm{KCl}, 4.53 \mathrm{~g} \mathrm{MgCl}_{2} .6 \mathrm{H}_{2} \mathrm{O}, 5.94 \mathrm{~g} \mathrm{MgSO}_{4} .7 \mathrm{H}_{2} \mathrm{O}$ and $1.3 \mathrm{~g} \mathrm{CaCl}_{2} \cdot 2 \mathrm{H}_{2} \mathrm{O}$ (Levring, 1946). Hydrolysis of hypoxanthine, tyrosine and xanthine was examined on MA plates with substrate concentrations as described by Cowan \& Steel (1965). $\mathrm{H}_{2} \mathrm{~S}$ production was tested as described by Bruns et al. (2001). Acid production from carbohydrates was determined as described by Leifson (1963). Utilization of various substrates for growth was determined as described by Yurkov et al. (1994).

Strains SW $-46^{\mathrm{T}}$ and $\mathrm{SW}-52^{\mathrm{T}}$ had identical morphological characteristics for their cells and colonies. Cells of both strains were rods, approximately $0 \cdot 7-0 \cdot 9 \mu \mathrm{m}$ wide and $1 \cdot 5-2 \cdot 5 \mu \mathrm{m}$ long after 3 days cultivation at $30^{\circ} \mathrm{C}$ on MA. Gram-staining reaction was negative. Cells of strains SW$46^{\mathrm{T}}$ and SW-52 had a single polar flagellum and no spores were observed. Colonies on MA were yellow, smooth, glistening, circular, convex with entire margins and $1 \cdot 0$ $1.5 \mathrm{~mm}$ in diameter after 3 days incubation at $30^{\circ} \mathrm{C}$. Cell morphologies of strains $\mathrm{SW}-46^{\mathrm{T}}$ and $\mathrm{SW}-52^{\mathrm{T}}$ were similar to those of Erythrobacter species, whereas colonies of the two strains were similar to those of E. citreus but different in colour from those of E. longus and E. litoralis (Table 1) (Shiba \& Simidu, 1982; Yurkov et al., 1994; Denner et al., 2002). Strains $S W-46^{T}$ and $S W-52$ were similar in most of their cultural and physiological characteristics: they grew optimally at $30-37^{\circ} \mathrm{C}$ and grew at 10 and $42^{\circ} \mathrm{C}$, but not at $4{ }^{\circ} \mathrm{C}$ or above $43^{\circ} \mathrm{C}$. The optimal $\mathrm{pH}$ for growth was $6 \cdot 5-7 \cdot 5$; no growth was observed at $\mathrm{pH} 4 \cdot 5$. Strains SW $-46^{\mathrm{T}}$ and SW-52 grew optimally in the presence of $2-5 \%(\mathrm{w} / \mathrm{v})$ $\mathrm{NaCl}$, but did not grow without $\mathrm{NaCl}$. Strain $\mathrm{SW}-46^{\mathrm{T}}$ did not grow in the presence of $>14 \% \mathrm{NaCl}$ and strain SW-52 did not grow in the presence of $>13 \% \mathrm{NaCl}$. Neither strain grew on MA under anaerobic conditions. Both strains showed catalase, oxidase and urease activities. Starch, Tween 80 and tyrosine were hydrolysed. No hydrolysis of aesculin, casein, gelatin, hypoxanthine or xanthine was observed. $\mathrm{H}_{2} \mathrm{~S}$ was not produced. Nitrate was not reduced to nitrite. Acid was produced from D-cellobiose and maltose. Acid production from D-trehalose was found only in strain SW-52. Acetate, butyrate and pyruvate were utilized for growth. Bacteriochlorophyll $a$ was not detected in vitro in either strain. Phenotypic characteristics of strains $\mathrm{SW}-46^{\mathrm{T}}$ and SW-52 were compared with those of Erythrobacter species (Table 1); strains SW-46 ${ }^{\mathrm{T}}$ and SW-52 were found to have physiological properties that were distinguishable from those of other Erythrobacter species.

Respiratory lipoquinones were analysed by using reversedphase HPLC (Komagata \& Suzuki, 1987). For quantitative analysis of cellular fatty acid composition, a loop of cell mass was harvested and FAMEs were prepared and identified by following the instructions of the Microbial Identification system (MIDI). The DNA G $+\mathrm{C}$ content was determined by the method of Tamaoka \& Komagata (1984); DNA was hydrolysed and the resultant nucleotides were analysed by reversed-phase HPLC.

The predominant respiratory lipoquinone of strains $\mathrm{SW}-46^{\mathrm{T}}$ and SW-52, E. longus DSM $6997^{\mathrm{T}}$ and E. litoralis DSM $8509^{\mathrm{T}}$ was ubiquinone-10 (Q-10), the same as that of E. citreus (Denner et al., 2002). Cellular fatty acid profiles of strains SW-46 ${ }^{\mathrm{T}}$ and SW-52 are shown in Table 2, together with those of E. longus DSM $6997^{\mathrm{T}}$, E. litoralis DSM $8509^{\mathrm{T}}$ and E. citreus $\mathrm{RE} 35 \mathrm{~F} / 1^{\mathrm{T}}$. Strains $\mathrm{SW}-46^{\mathrm{T}}$ and $\mathrm{SW}-52$ had cellular fatty acid profiles that contained large amounts of saturated and unsaturated fatty acids (Table 2). The major fatty acid found in strains $S W-46^{\mathrm{T}}$ and $\mathrm{SW}-52$ was $\mathrm{C}_{18: 1} \omega 7 c$, at a peak ratio of approximately $45-46 \%$ (Table 2 ). The fatty acid profiles of the two strains were similar to those of the type

Table 2. Cellular fatty acid profiles of Erythrobacter species

Strains: 1, E. flavus SW-46 ${ }^{\mathrm{T}}$; 2, E. flavus SW-52; 3, E. longus DSM $6997^{\mathrm{T}}$; 4, E. litoralis DSM $8509^{\mathrm{T}}$; 5, E. citreus $\mathrm{RE} 35 \mathrm{~F} / 1^{\mathrm{T}}$. Values are percentage of total fatty acids. -, Not detected. Fatty acids that represented $<0.5 \%$ in all strains were omitted.

\begin{tabular}{|c|c|c|c|c|c|}
\hline Fatty acid & 1 & 2 & 3 & 4 & $5^{*}$ \\
\hline \multicolumn{6}{|l|}{ Saturated: } \\
\hline $\mathrm{C}_{15: 0}$ & $3 \cdot 0$ & $3 \cdot 4$ & $2 \cdot 8$ & $0 \cdot 5$ & $0 \cdot 3$ \\
\hline $\mathrm{C}_{16: 0}$ & $6 \cdot 4$ & $7 \cdot 6$ & $11 \cdot 4$ & $2 \cdot 7$ & $8 \cdot 2$ \\
\hline $\mathrm{C}_{17: 0}$ & $7 \cdot 3$ & $8 \cdot 3$ & $10 \cdot 1$ & - & - \\
\hline $\mathrm{C}_{18: 0}$ & $0 \cdot 5$ & $0 \cdot 5$ & $1 \cdot 0$ & - & - \\
\hline \multicolumn{6}{|l|}{ Branched: } \\
\hline anteiso- $\mathrm{C}_{15: 0}$ & - & - & - & - & $0 \cdot 6$ \\
\hline anteiso- $\mathrm{C}_{16: 0}$ & - & - & - & - & $0 \cdot 7$ \\
\hline anteiso- $\mathrm{C}_{17: 0}$ & - & - & - & - & $1 \cdot 2$ \\
\hline \multicolumn{6}{|l|}{ Unsaturated: } \\
\hline $\mathrm{C}_{16: 1} \omega 5 c$ & - & - & - & $0 \cdot 7$ & $3 \cdot 6$ \\
\hline $\mathrm{C}_{17: 1} \omega 6 c$ & $6 \cdot 2$ & $5 \cdot 1$ & $3 \cdot 9$ & $28 \cdot 5$ & $5 \cdot 6$ \\
\hline $\mathrm{C}_{17: 1} \omega 8 c$ & $8 \cdot 1$ & $6 \cdot 7$ & $4 \cdot 8$ & $4 \cdot 3$ & $0 \cdot 7$ \\
\hline $\mathrm{C}_{18: 1} \omega 5 c$ & - & - & - & $2 \cdot 2$ & $4 \cdot 2$ \\
\hline $\mathrm{C}_{18: 1} \omega 7 c$ & $46 \cdot 2$ & $44 \cdot 9$ & $50 \cdot 9$ & $46 \cdot 9$ & $49 \cdot 3$ \\
\hline $11-$ Methyl- $\mathrm{C}_{18: 1} \omega 7 c$ & $5 \cdot 5$ & $7 \cdot 1$ & - & $3 \cdot 7$ & $4 \cdot 4$ \\
\hline \multicolumn{6}{|l|}{ Hydroxy: } \\
\hline $\mathrm{C}_{14: 0} 2-\mathrm{OH}$ & $0 \cdot 9$ & $0 \cdot 9$ & $5 \cdot 0$ & $2 \cdot 9$ & $0 \cdot 9$ \\
\hline $\mathrm{C}_{15: 0} 2-\mathrm{OH}$ & $9 \cdot 5$ & $8 \cdot 7$ & $8 \cdot 6$ & $2 \cdot 6$ & - \\
\hline $\mathrm{C}_{16: 0} 2-\mathrm{OH}$ & $1 \cdot 4$ & $1 \cdot 3$ & $1 \cdot 5$ & $1 \cdot 5$ & - \\
\hline $\mathrm{C}_{18: 1} 2-\mathrm{OH}$ & $0 \cdot 3$ & $0 \cdot 4$ & - & - & $2 \cdot 0$ \\
\hline iso- $\mathrm{C}_{16: 0} 3-\mathrm{OH}$ & - & - & - & $1 \cdot 1$ & $1 \cdot 0$ \\
\hline Summed feature $3 \dagger$ & $4 \cdot 6$ & $4 \cdot 9$ & - & $2 \cdot 3$ & $14 \cdot 9$ \\
\hline
\end{tabular}

${ }^{\star}$ Data from Denner et al. (2002).

$\dagger$ Summed features represent groups of two or three fatty acids that could not be separated by GLC with the MIDI system. Summed feature 3 contained iso- $\mathrm{C}_{15: 0} 2-\mathrm{OH}$ and/or $\mathrm{C}_{16: 1} \omega 7 c$. 
strains of E. longus and E. citreus. The fatty acid profile of E. longus DSM $6997^{\mathrm{T}}$ obtained in this study was similar to that reported by Fuerst et al. (1993). However, there was a noteworthy difference in the proportion of $\mathrm{C}_{17: 1} \omega 6 \mathrm{c}$ between strains SW- $46^{\mathrm{T}}$ and SW-52 and E. litoralis DSM $8509^{\mathrm{T}}$. The DNA G+C contents of strains $\mathrm{SW}-46^{\mathrm{T}}$ and SW-52 were $64 \cdot 0$ and $64 \cdot 1 \mathrm{~mol} \%$, respectively.

Chromosomal DNA was isolated and purified according to a method described previously (Yoon et al., 1996), with the exception that ribonuclease $\mathrm{T} 1$ was used together with ribonuclease A. $16 \mathrm{~S}$ rDNA was amplified by PCR with two universal primers, as described previously (Yoon et al., 1998). The PCR product was purified by using a QIAquick PCR Purification kit (Qiagen). Sequencing of the purified $16 \mathrm{~S}$ rDNA was performed by using an ABI PRISM BigDye Terminator cycle sequencing ready reaction kit (Applied Biosystems) as recommended by the manufacturer. The purified sequencing reaction mixtures were electrophoresed automatically by using an Applied Biosystems model 377 automatic DNA sequencer. Alignment of sequences was carried out with CLUSTAL W software (Thompson et al., 1994). Gaps at the 5' and 3' ends of the alignment were omitted from further analysis. Phylogenetic trees were inferred by using three tree-making algorithms: the neighbour-joining (Saitou \& Nei, 1987), maximum-likelihood (Felsenstein, 1981) and maximum-parsimony (Kluge \& Farris, 1969) methods in the PHYLIP package (Felsenstein, 1993). Evolutionary distance matrices for the neighbour-joining method were calculated by using the algorithm of Jukes \& Cantor (1969) with the program DNADIST. The stability of relationships was assessed by bootstrap analysis based on 1000 resamplings of the neighbour-joining dataset, by using the programs SEQBOOT, DNADIST, NEIGHBOR and CONSENSE of the PHYLIP package.

The 16S rDNA sequences of two strains determined in this study each comprised 1442 nucleotides, which represents approximately $96 \%$ of the Escherichia coli $16 \mathrm{~S}$ rRNA gene sequence. There is only $1 \mathrm{bp}$ difference between the $16 \mathrm{~S}$ rDNA sequences of strains SW $-46^{\mathrm{T}}$ and SW-52. The strains were found to have highest $16 \mathrm{~S}$ rDNA similarity to members of the $\alpha$-Proteobacteria. Strains SW- $46^{\mathrm{T}}$ and SW-52 exhibited 16S rDNA similarity levels of $96 \cdot 5-97 \cdot 9 \%$ with the type strains of E. longus, E. litoralis and E. citreus, but $<96.5 \%$ to other species used in the phylogenetic analysis. In the phylogenetic tree based on the neighbour-joining algorithm, strains SW- $46^{\mathrm{T}}$ and $\mathrm{SW}-52$ formed a coherent cluster with E. citreus, E. longus and E. litoralis (Fig. 1). The relationship between this cluster and the clade that comprised the genera Erythromicrobium and Porphyrobacter was supported by a bootstrap confidence level of $100 \%$. This tree topology was also generated by the maximum-parsimony and maximum-likelihood algorithms (data not shown). When the neighbour-joining and maximum-parsimony algorithms were used, the relationship between the cluster that comprised strains SW- $46^{\mathrm{T}}$ and SW-52 and Erythrobacter species and the clade that comprised the genera Porphyrobacter

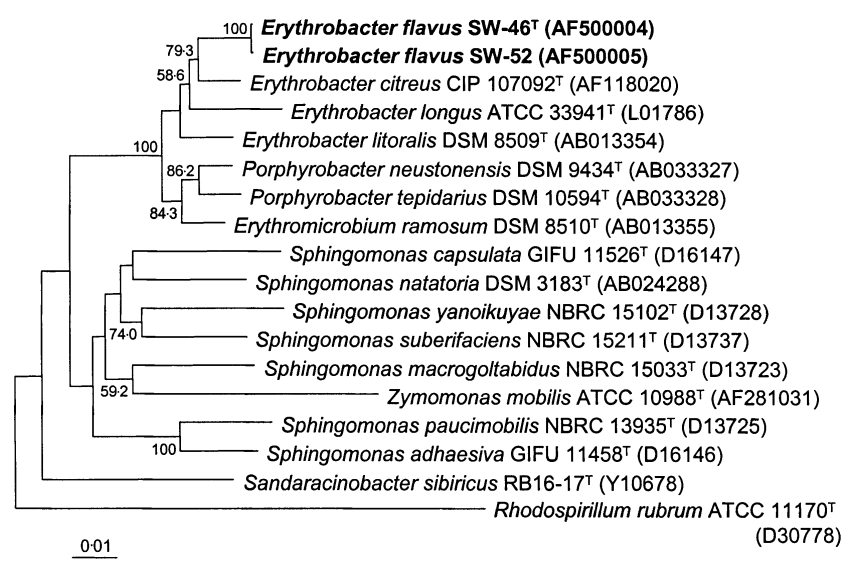

Fig. 1. Neighbour-joining tree showing the phylogenetic positions of Erythrobacter flavus sp. nov. SW $-46^{\top}$ and SW-52 and representatives of related taxa, based on 16S rDNA sequences. Bootstrap values (expressed as percentages of 1000 replications) greater than $50 \%$ are shown at branch-points. Bar, 0.01 substitutions per nucleotide position.

and Erythromicrobium was supported by high bootstrap resampling values.

DNA-DNA hybridization was performed fluorometrically by using photobiotin-labelled DNA probes and microdilution wells (Ezaki et al., 1989). Hybridization was performed with five replications for each sample. Of the values obtained, the highest and lowest values for each sample were excluded; DNA relatedness values are means of the remaining three values. Strains SW- $46^{\mathrm{T}}$ and SW-52 exhibited DNA-DNA relatedness levels of $94 \cdot 0$ and $94 \cdot 7 \%$ when their DNA was used individually as a labelled DNA probe. Accordingly, by considering the criterion of DNA-DNA similarity for definition of a species in current bacterial systematics (Wayne et al., 1987), strains SW- $46^{\mathrm{T}}$ and SW-52 should be classified as members of the same species. Levels of DNADNA relatedness between strains SW- $46^{\mathrm{T}}$ and SW-52 and the type strains of E. longus, E. litoralis and E. citreus are shown in Table 3; they support the conspicuous genomic distinctiveness of strains SW- $46^{\mathrm{T}}$ and SW-52.

Phenotypically, strains $\mathrm{SW}-46^{\mathrm{T}}$ and $\mathrm{SW}-52$ are similar to E. citreus in pigmentation and the absence of

Table 3. Levels of DNA-DNA relatedness

\begin{tabular}{|lcc|}
\hline \multirow{2}{*}{ Strain } & \multicolumn{2}{c|}{ Reassociation with (\%) } \\
\cline { 2 - 3 } & Strain SW-46 $^{\mathrm{T}}$ & Strain SW-52 \\
\hline Strain SW-46 & 100 & $94 \cdot 7$ \\
Strain SW-52 & $94 \cdot 0$ & 100 \\
E. longus DSM $6997^{\mathrm{T}}$ & $4 \cdot 2$ & $3 \cdot 6$ \\
E. litoralis DSM $8509^{\mathrm{T}}$ & $6 \cdot 0$ & $7 \cdot 4$ \\
E. citreus DSM $14432^{\mathrm{T}}$ & $13 \cdot 1$ & $14 \cdot 7$ \\
\hline
\end{tabular}


bacteriochlorophyll $a$, and are different in these respects from E. longus and E. litoralis. The $16 \mathrm{~S}$ rDNA sequence analysis provides evidence that both strains belong to the Erythrobacter $16 \mathrm{~S}$ rDNA cluster. In this study, cellular fatty acid and respiratory lipoquinone analyses were performed on the type strains of E. longus and E. litoralis, as well as on strains SW $-46^{\mathrm{T}}$ and SW-52; the results have been compared with those of E. citreus. The predominant respiratory lipoquinone and fatty acid profiles of strains $\mathrm{SW}-46^{\mathrm{T}}$ and SW-52 were found to be similar to those of the type strains of the other Erythrobacter species, confirming their intrageneric relationship. In view of these combined morphological, chemotaxonomic and phylogenetic analyses, strains SW- $46^{\mathrm{T}}$ and SW-52 warrant classification in the genus Erythrobacter. The level of DNA-DNA relatedness and phenotypic characteristics confirmed that the strains constitute a separate species. Therefore, on the basis of the data presented, we propose to include strains SW- $46^{\mathrm{T}}$ and SW-52 in the genus Erythrobacter as Erythrobacter flavus sp. nov.

\section{Description of Erythrobacter flavus sp. nov.}

Erythrobacter flavus (fla'vus. L. masc. adj. flavus yellow, the colour of colonies or pigment).

Non-spore-forming rods, $0.7-0.9 \times 1.5-2.5 \mu \mathrm{m}$ on MA. Gram-staining reaction is negative. Motile by means of a single polar flagellum. Colonies are yellow, smooth, glistening, circular, convex with entire margins and $1 \cdot 0-1.5 \mathrm{~mm}$ in diameter after 3 days cultivation at $30^{\circ} \mathrm{C}$ on MA. Optimal temperature for growth is $30-37^{\circ} \mathrm{C}$. Growth occurs at 10 and $42^{\circ} \mathrm{C}$, but not at $4{ }^{\circ} \mathrm{C}$ or above $43^{\circ} \mathrm{C}$. Optimal $\mathrm{pH}$ for growth is $6 \cdot 5-7 \cdot 5$. Growth occurs at $\mathrm{pH} 5 \cdot 0$, but not at $\mathrm{pH} 4 \cdot 5$. Optimal growth occurs in the presence of $2-5 \%(\mathrm{w} / \mathrm{v}) \mathrm{NaCl}$. No growth occurs in the absence of $\mathrm{NaCl}$ or in the presence of $>14 \% \mathrm{NaCl}$. No growth occurs under anaerobic conditions on MA. Catalase-, oxidase- and urease-positive. Starch, Tween 80 and tyrosine are hydrolysed. Aesculin, casein, gelatin, hypoxanthine and xanthine are not hydrolysed. $\mathrm{H}_{2} \mathrm{~S}$ is not produced. Nitrate is not reduced to nitrite. Susceptible to chloramphenicol. Resistant to penicillin, streptomycin and polymyxin B. Acid is produced from D-cellobiose and maltose. Acid production from D-trehalose is variable. Acid is not produced from adonitol, L-arabinose, D-fructose, Dgalactose, D-glucose, myo-inositol, lactose, D-mannitol, Dmannose, D-melezitose, melibiose, D-raffinose, L-rhamnose, D-ribose, D-sorbitol, stachyose, sucrose or D-xylose. Acetate, butyrate and pyruvate are utilized for growth. Glucose, fructose, glutamate, citrate, malate, succinate, formate, methanol, ethanol and benzoate are not utilized. Utilization of lactate is variable. The predominant respiratory lipoquinone is ubiquinone-10. The major fatty acid is $\mathrm{C}_{18: 1} \omega 7 c$. The DNA G $+\mathrm{C}$ content is $64 \cdot 0-64 \cdot 1 \mathrm{~mol} \%$ (determined by HPLC).

The type strain $\left(\mathrm{SW}-46^{\mathrm{T}}=\mathrm{KCCM} 41642^{\mathrm{T}}=\mathrm{JCM} 11808^{\mathrm{T}}\right)$ and reference strain $(S W-52=$ KCCM $41643=J C M 11809)$ were isolated from sea water of Hwajinpo Beach, East Sea, Korea.

\section{Acknowledgements}

J.-H.Y. and H.K. contributed equally to this work. This work was supported by grant HSS0310134 and the NRL research programme (grants M10104000294-01J000012800 and NLW0070111) from the Ministry of Science and Technology (MOST) of the Republic of Korea, and by the research fund of the Probionic Corporation of Korea.

\section{References}

Anzai, Y., Kim, H., Park, J.-Y., Wakabayashi, H. \& Oyaizu, H. (2000). Phylogenetic affiliation of the pseudomonads based on 16S rRNA sequence. Int J Syst Evol Microbiol 50, 1563-1589.

Bruns, A., Rohde, M. \& Berthe-Corti, L. (2001). Muricauda ruestringensis gen. nov., sp. nov., a facultatively anaerobic, appendaged bacterium from German North Sea intertidal sediment. Int J Syst Evol Microbiol 51, 1997-2006.

Cowan, S. T. \& Steel, K. J. (1965). Manual for the Identification of Medical Bacteria. London: Cambridge University Press.

Denner, E. B. M., Vybiral, D., Kobližek, M., Kämpfer, P., Busse, H.-J. \& Velimirov, B. (2002). Erythrobacter citreus sp. nov., a yellowpigmented bacterium that lacks bacteriochlorophyll $a$, isolated from the western Mediterranean Sea. Int J Syst Evol Microbiol 52, 1655-1661.

Ezaki, T., Hashimoto, Y. \& Yabuuchi, E. (1989). Fluorometric deoxyribonucleic acid- deoxyribonucleic acid hybridization in microdilution wells as an alternative to membrane filter hybridization in which radioisotopes are used to determine genetic relatedness among bacterial strains. Int J Syst Bacteriol 39, 224-229.

Felsenstein, J. (1981). Evolutionary trees from DNA sequences: a maximum likelihood approach. J Mol Evol 17, 368-376.

Felsenstein, J. (1993). PHYLIP (phylogeny inference package), version 3.5c. Department of Genetics, University of Washington, Seattle, USA.

Fuerst, J. A., Hawkins, J. A., Holmes, A., Sly, L. I., Moore, C. J. \& Stackebrandt, E. (1993). Porphyrobacter neustonensis gen. nov., sp. nov., an aerobic bacteriochlorophyll-synthesizing budding bacterium from fresh water. Int J Syst Bacteriol 43, 125-134.

Jukes, T. H. \& Cantor, C. R. (1969). Evolution of protein molecules. In Mammalian Protein Metabolism, pp. 21-132. Edited by H. N. Munro. New York: Academic Press.

Kluge, A. G. \& Farris, J. S. (1969). Quantitative phyletics and the evolution of anurans. Syst Zool 18, 1-32.

Komagata, K. \& Suzuki, K. (1987). Lipids and cell-wall analysis in bacterial systematics. Methods Microbiol 19, 161-203.

Lányi, B. (1987). Classical and rapid identification methods for medically important bacteria. Methods Microbiol 19, 1-67.

Leifson, E. (1963). Determination of carbohydrate metabolism of marine bacteria. J Bacteriol 85, 1183-1184.

Levring, T. (1946). Some culture experiments with Ulva and artificial seawater. K Fysiogr Sällsk Lund Förh 16, 45-56.

Saitou, N. \& Nei, M. (1987). The neighbor-joining method: a new method for reconstructing phylogenetic trees. Mol Biol Evol 4, 406-425.

Shiba, T. (1991). Roseobacter litoralis gen. nov., sp. nov., and Roseobacter denitrificans sp. nov., aerobic pink-pigmented bacteria which contain bacteriochlorophyll a. Syst Appl Microbiol 14, 140-145.

Shiba, T. \& Simidu, U. (1982). Erythrobacter longus gen. nov., sp. nov., an aerobic bacterium which contains bacteriochlorophyll $a$. Int J Syst Bacteriol 32, 211-217. 
Tamaoka, J. \& Komagata, K. (1984). Determination of DNA base composition by reverse-phase high-performance liquid chromatography. FEMS Microbiol Lett 25, 125-128.

Thompson, J. D., Higgins, D. G. \& Gibson, T. J. (1994). CLUSTAL W: improving the sensitivity of progressive multiple sequence alignment through sequence weighting, position-specific gap penalties and weight matrix choice. Nucleic Acids Res 22, 4673-4680.

Vybiral, D., Denner, E. B. M., Haller, C. M., Busse, H.-J., Witte, A., Höfle, M. G. \& Velimirov, B. (1999). Polyphasic classification of $0 \cdot 2 \mu \mathrm{m}$ filterable bacteria from the western Mediterranean Sea. Syst Appl Microbiol 22, 635-646.

Wayne, L. G., Brenner, D. J., Colwell, R. R. \& 9 other authors (1987). International Committee on Systematic Bacteriology. Report of the ad hoc committee on reconciliation of approaches to bacterial systematics. Int J Syst Bacteriol 37, 463-464.

Yoon, J.-H., Kim, H., Kim, S.-B., Kim, H.-J., Kim, W. Y., Lee, S. T., Goodfellow, M. \& Park, Y.-H. (1996). Identification of Saccharomonospora strains by the use of genomic DNA fragments and rRNA gene probes. Int J Syst Bacteriol 46, 502-505.

Yoon, J.-H., Lee, S. T. \& Park, Y.-H. (1998). Inter- and intraspecific phylogenetic analysis of the genus Nocardioides and related taxa based on 16S rDNA sequences. Int J Syst Bacteriol 48, 187-194.

Yurkov, V., Stackebrandt, E., Holmes, A. \& 7 other authors (1994). Phylogenetic positions of novel aerobic, bacteriochlorophyll a-containing bacteria and description of Roseococcus thiosulfatophilus gen. nov., sp. nov., Erythromicrobium ramosum gen. nov., sp. nov., and Erythrobacter litoralis sp. nov. Int J Syst Bacteriol 44, 427-434. 